\title{
Epidemiology of coronavirus respiratory infections
}

\author{
D ISAACS, D FLOWERS, J R CLARKE, H B VALMAN, AND M R MACNAUGHTON \\ Division of Communicable Diseases, Clinical Research Centre and Department of Paediatrics, Northwick \\ Park Hospital, Harrow
}

SUMMARY Human coronaviruses were found by enzyme linked immunosorbent assay in upper respiratory tract secretions taken during $30 \%$ of 108 acute respiratory infections experienced by 30 children under age 6 years with recurrent respiratory infections (index group), and during $29 \%$ of 51 acute infections experienced by their siblings. Lower respiratory tract infection-predominantly wheezy bronchitis-occurred in $30 \%$ of the index children's coronavirus positive infections but in none of their siblings' infections. Reinfections were common. Two peaks of infection were seen each year in the late autumn/early winter and in the early summer.

Many human coronavirus (HCV) isolates have been reported to cause upper respiratory tract infections in both children and adults. ${ }^{12}$ These isolates all fall into 1 of 2 distinct antigenic groups, ${ }^{13} 4$ named after the prototype strains, $\mathrm{HCV} 229 \mathrm{E}^{5}$ and $\mathrm{HCV}$ OC43. ${ }^{6}$ Coronaviruses cause wheezing in young asthmatic children ${ }^{7}$ but only rarely cause wheezing in normal children. ${ }^{8-10}$ The clinical features of HCV OC43 infection in childhood have been well described, ${ }^{11}$ but not those of HCV 229E.

Previous epidemiological studies on $\mathrm{HCV}$ respiratory infections in children have been based on serological evidence of infection ${ }^{811-14}$ because the difficulties in growing HCVs in conventional tissue and organ cultures make direct isolation difficult. The disadvantage of serological studies is that they need at least 2 serum samples taken several weeks or more apart. We have recently developed an enzyme linked immunosorbent assay (ELISA) for detecting HCV antigens in nasal secretions from children with respiratory infections. ${ }^{15}$ This assay needs only a single sample of a nasal secretion taken at the peak of infection. We describe a prospective study of acute respiratory infections in children and the epidemiological features of infection with HCV 229E and HCV OC43 group viruses found in samples of nasal secretions by ELISA.

\section{Patients and methods}

Thirty children aged 6 months to 6 years presenting consecutively to the paediatric department of this hospital with recurrent upper or lower respiratory tract infections were admitted to a prospective study. The index group children were reported by their parents as having had at least 10 infections in the previous year and all had an unaffected sibling in the same age range who acted as control. Each sibling pair was followed prospectively for 1 year from admission to the study, which was carried out from October 1979 to February 1981. These children have been described in detail. ${ }^{16} 17$

Index and control children were visited at home by DI during each acute respiratory illness. A clinical diagnosis, made according to the criteria of Court, ${ }^{18}$ was recorded along with records of signs and symptoms, and the parents kept a record card of subsequent progress. Because this study was done on patients at home and not in hospital, pneumonia was generally diagnosed on the clinical grounds of diminished air entry and crepitations, as used in studies of acute respiratory illness in general practice. ${ }^{1920}$ Nose and throat swabs were taken with sterile wool swabs and broken into viral transport medium containing penicillin, streptomycin, and amphotericin. A neonatal mucus extractor and mucus trap was used to take a nasopharyngeal aspirate, to which was added $2 \mathrm{ml}$ of viral transport medium. Specimens were taken to the laboratory frozen on solid carbon dioxide and stored at $-70^{\circ} \mathrm{C}$ until inoculated onto cell culture. ${ }^{17}$ Organ cultures were not used.

Antisera to HCV 229E and CV Paris, a virus antigenically closely related to $\mathrm{HCV} O C 43,{ }^{21}$ were prepared in New Zealand White rabbits ${ }^{22}$ from sucrose gradient purified virus preparations..$^{15}$ These antisera were then used in ELISAs to detect HCV 229E and HCV OC43 group viruses in the nasal secretions of the children. The method used and the criteria for identifying which specimens contained HCV antigens have been described. ${ }^{15}$

One hundred and fifty nine samples were tested- 
108 from index children and 51 from control siblings. The 159 samples were approximately $40 \%$ of all specimens collected. A hundred and four of the samples were nose swabs, 50 were nasopharyngeal aspirates, and 5 were throat swabs. There was no deliberate selection of which specimens to test, but nose swabs were selected over nasopharyngeal aspirates and throat swabs when more than 1 type of specimen was available for each infectious illness, and specimens from which respiratory viruses had been isolated in tissue culture were less likely to be used as the original specimen had often been used in other tests. Analysis by ELISA of some of these specimens has been described. ${ }^{15}$ Ethical committee approval was obtained.

\section{Results}

Table 1 shows the number of specimens tested from index and control children that were positive for HCVs. Twenty seven per cent were positive for HCV $229 \mathrm{E}$ group viruses alone, $1 \%$ were positive for HCV OC43 group viruses alone, and $2 \%$ for both HCV groups. HCVs were found in a similar proportion of specimens from the index and control children-the detection rates were $31 \%$ and $29 \%$ respectively. Five of the HCV positive samples were also positive for other viruses (4 rhinoviruses and 1 echovirus). Bacterial flora of the nose and throat during these respiratory infections were no different from when the children were symptom free.

Table 1 Number of children's nasal specimens positive for human coronaviruses (HCV) by ELISA

\begin{tabular}{lllll}
\hline Group & No of samples & \multicolumn{4}{l}{ HCV group } \\
\cline { 2 - 5 } & & $229 E$ & $229 E$ and OC43 & OC43 \\
\hline Index & 108 & 30 & 2 & 1 \\
Control & 51 & 13 & 1 & 1 \\
\hline
\end{tabular}

The respiratory signs and symptoms of preschool children with HCV infections are shown in Table 2 and the clinical diagnoses made in association with each infection in Table 3. The diagnoses in dual infections (HCV and another virus) have been added in parentheses to show that these do not alter materially our results or conculsions.

The index children had lower respiratory tract infections, predominantly wheezy bronchitis, during $10(30 \%)$ of their HCV infections, whereas HCV infections in the control children were of the upper respiratory tract only. We have seen a similar clinical pattern with other respiratory virus infections: the index children were more likely than their siblings to wheeze during respiratory virus infections and this was not due solely to atopy. ${ }^{17}$

Six children had reinfections with HCVs after disappearance of the antigen in intervening specimens and 1 of these children had 2 reinfections. In 4 children the antigen was present in consecutive

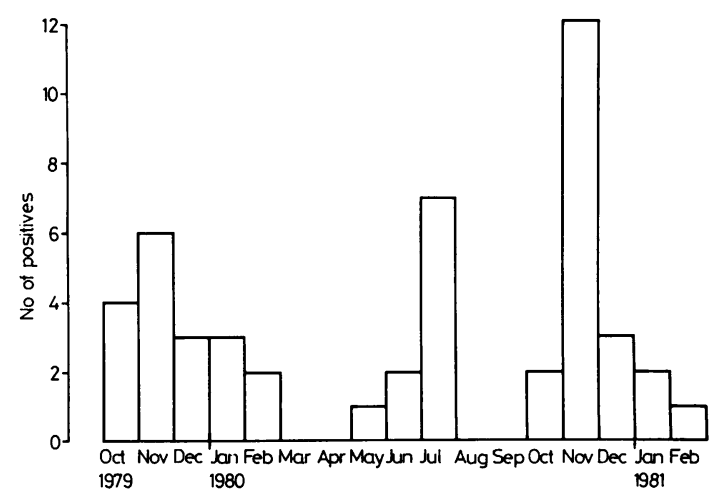

Figure Temporal distribution of human coronavirus positive secretions from acute respiratory tract infections.

Table 2 Respiratory signs and symptoms in human coronavirus infections of preschool children

\begin{tabular}{lcccccccccc}
\hline Group & Rhinitis & Fever & Cough & $\begin{array}{l}\text { Tonsillitis or } \\
\text { pharyngitis }\end{array}$ & $\begin{array}{l}\text { Cervical } \\
\text { adenitis }\end{array}$ & $\begin{array}{l}\text { Pink ear } \\
\text { drums }\end{array}$ & Otitis media & Croup & Wheeze & $\begin{array}{c}\text { Diminished air } \\
\text { entry and rales }\end{array}$ \\
\hline Index $(\mathrm{n}=33)$ & 25 & 24 & 20 & 18 & 15 & 12 & 2 & 1 & 8 & 2 \\
Control $(\mathrm{n}=15)$ & 12 & 8 & 6 & 8 & 5 & 5 & 0 & 0 & 0 & 0 \\
\hline
\end{tabular}

Table 3 Clinical diagnoses in human coronavirus ( $\mathrm{HCV}$ ) infections of preschool children

\begin{tabular}{|c|c|c|c|c|c|c|c|}
\hline Group & Coryza & $\begin{array}{l}\text { Upper respiratory } \\
\text { tract infection }\end{array}$ & $\begin{array}{l}\text { Tonsillitis or } \\
\text { pharyngitis }\end{array}$ & Otitis media & Croup & Wheezy bronchitis & Pneumonia \\
\hline $\begin{array}{l}\text { Index } \\
\text { Control }\end{array}$ & $\begin{array}{l}7 \\
7(1)\end{array}$ & $\begin{array}{l}7(1) \\
5\end{array}$ & $\begin{array}{l}6(1) \\
3\end{array}$ & $\begin{array}{l}2 \\
0\end{array}$ & $\begin{array}{l}1 \\
0\end{array}$ & $\begin{array}{l}8(2) \\
0\end{array}$ & $\begin{array}{l}2 \\
0\end{array}$ \\
\hline
\end{tabular}

Numbers in parentheses indicate dual infections with HCV and another virus. 
specimens taken from separate illnesses 13 to 29 days apart, and 4 further children had antigen in consecutive specimens 2 or 3 months apart (65 to 105 days). This may mean either reinfection or that they are carriers of HCVs.

Three peaks of $\mathrm{HCV}$ infection were observed during the 18 months of the study (Figure): 2 in the late autumn/early winter of 1979 and 1980 and 1 in the early summer of 1980 . No HCV infections were found in the months between these peaks.

\section{Discussion}

We have shown that coronaviruses were found in $30 \%$ of acute respiratory tract infections of children under 6 years between October 1979 and February 1980. This may be an over estimate as specimens from which other respiratory viruses had been isolated were less likely to be used (see above). Similar results were obtained by Monto and Lim who found that children under 5 years had a $29 \%$ infection rate with HCV OC43.14 These studies cannot be readily compared, however, as we found $\mathrm{HCV}$ infections by measuring antigen in nasal secretions, whereas Monto and Lim detected HCV infections by serological techniques.

We also confirmed McIntosh's suggestion? that coronaviruses may be important precipitants of asthmatic attacks in young asthmatic children. Our index children had lower respiratory tract infections, predcminantly wheezy bronchitis, during $30 \%$ of HCV infections. We showed that these children were more likely than their siblings to wheeze during all respiratory virus infections but that this was not due solely to atopy, and we suggested that the index children were less efficient at eradicating respiratory viruses from their upper respiratory tract. ${ }^{17}$

One problem in the interpretation of our results is uncertainty as to how often HCV occurred in conjunction with other respiratory pathogens that we could not detect. This is a common problem in epidemiological studies of acute respiratory infections, in which even the most rigorous search for respiratory viruses may yield a detection rate of only 20 to $30 \%$. We isolated respiratary virusesexcluding coronaviruses-from $38 \%$ of all acute respiratory infections, however, ${ }^{17}$ and believe that undetected pathogens would not have altered materially our epidemiological conclusions.

Reinfections with HCVs were common. Furthermore, we found HCVs in secretions taken from consecutive acute infections more than 3 months apart. This may show that the virus is carried in the upper respiratory tract: it is known that adenoviruses are carried for many months. ${ }^{23}$ Three of the specimens tested were positive for both HCV 229E and HCV OC43 group viruses: this could be caused by simultaneous $\mathrm{HCV}$ infections or by a single infection with an HCV bearing common antigens.

Infections caused by HCV $229 \mathrm{E}$ and HCV OC43 group viruses follow a complex pattern, although they usually occur in 2 to 3 year cycles. ${ }^{12}{ }^{7-12} 14$ In general, high infection rates in any particular year are caused by either HCV 229E or HCV OC43 group viruses and there are sporadic infections only with HCVs belonging to the other group. During our study there was a high rate of infection caused by HCV 229E group viruses with only minor activity of the HCV OC43 group virus.

Studies in the USA have determined the periods of $\mathrm{HCV}$ infection by measuring the increase in antibodies to $\mathrm{HCVs}$ in selected populations. ${ }^{127-12} 14$ These results show that epidemics occur during the winter and early spring, with the peak period varying by several months. Other periods of high infection have, however, been observed. ${ }^{2} 8111214$ A recent study in the United Kingdom showed that HCV infections in adults occurred throughout the year with major peaks of infection during the summer as well as the winter. ${ }^{24}$ Our study shows that HCV infections of children also occur in both summer and winter months.

We acknowledge the generous financial assistance of the Medical Research Council and the Nuffield Foundation. We thank Dr D A J Tyrrell for advice and encouragement.

\section{References}

1 McIntosh K. Coronaviruses: a comparative review. Curr Microbiol Immunol 1974; 63: 85-129.

2 Monto AS. Coronaviruses. Yale J Biol Med 1974; 47: 234-51.

3 MacNaughton MR, Madge MH, Reed SE. Two antigenic groups of human coronaviruses detected by using enzymelinked immunosorbent assay. Infect Immun 1981; 33: 734-7.

4 McIntosh K, Kapikian AZ, Hardison KA, Hartley JW, Chanock RM. Antigenic relationships among the coronaviruses of man and between human and animal coronaviruses. J Immunol 1969; 102: 1109-18.

5 Hamre D, Procknow JJ. A new virus isolated from the human respiratory tract. Proc Soc Exp Biol Med 1966; 121 : 190-3.

6 McIntosh K, Becker WB, Chanock RM. Growth in suckling mouse brain of 'IBV-like' viruses from patients with upper respiratory tract disease. Proc Natl Acad Sci USA 1967; 58: 2268-73.

7 McIntosh K, Ellis EF, Hoffman LS, Lybass TG, Eller JJ, Fulginiti VA. The association of viral and bacterial respiratory infections with exacerbations of wheezing in young asthmatic children. $J$ Pediatr 1973 ; 82: 579-90.

8 McIntosh K, Kapikian AZ, Turner HC, Hartley JW, Parrott RM, Chanock RM. Seroepidemiologic studies of coronavirus infection in adults and children. $A m J$ Epidemiol 1970; 91 : 585-92. 
9 McIntosh K, Chao RK, Krause HE, Wasil R, Mosega HE, Mufson MA. Coronavirus infection in acute lower respiratory tract disease of infants. J Infect Dis 1974; 130: 502-7.

10 Mufson MA, McIntosh K, Chao RK, Krause HE, Wasil R, Mosega HE. Epidemiology of coronavirus infections in infants with acute lower respiratory disease (abstract). Clin Res 1972; 20: 534.

11 Kaye HS, Marsh HB, Dowdle WR. Sero-epidemiologic survey of coronavirus (strain OC43) related infections in a children's population. Am J Epidemiol 1971 ; 94: 43-9.

12 Cavallaro JJ, Monto AS. Community-wide outbreak of infection with 229E-like coronavirus in Tecumesh, Michigan. J Infect Dis 1970; 122: 272-9.

13 Kapikian AZ, James HD, Jr, Kelly SJ, et al. Isolation from man of 'avian infectious bronchitis virus-like' viruses (coronaviruses) similar to $229 \mathrm{E}$ virus with some epidemiological observations. J Infect Dis 1969; 119: 282-90.

14 Monto AS, Lim SK. The Tecumseh study of respiratory illness. VI. Frequency of and relationship between outbreaks of coronavirus infection. J Infect Dis 1974; 129: 271-6.

15 MacNaughton MR, Flowers D, Isaacs D. Diagnosis of human coronavirus infections in children using enzymelinked immunosorbent assay. $J$ Med Virol 1983: in press.

16 Isaacs D, Clarke JR, Tyrrell DAJ, Webster ADB, Valman HB. Deficiency of production of leucocyte interferon (interferon- $\alpha$ ) in vitro and in vivo in children with recurrent respiratory tract infections. Lancet 1981; ii: $950-2$.

17 Isaacs D, Clarke JR, Tyrrell DAJ, Valman HB. Selective infection of lower respiratory tract by respiratory viruses in children with recurrent respiratory tract infections. Br Med J 1982; 284: 1746-8.

18 Court SDM. The definition of acute respiratory illnesses in children. Postgrad Med J 1973; 49: 771-6.

19 Miller DL. Collaborative studies of acute respiratory disease in patients seen in general practice and in children admitted to hospital. Postgrad Med J 1973; 49: 746-62.

20 Hope-Simpson RE, Miller DL. The definition of acute respiratory illnesses in general practice. Postgrad Med $J$ 1973; 49: 763-70.

21 Hasony HJ, MacNaughton MR. Prevalence of human coronavirus antibody in the population of Southern Iraq. $J$ Med Virol 1982; 9: 209-16.

22 Kraaijeveld CA, Madge MH, MacNaughton MR. Enzyme-linked immunosorbent assay for coronavirus HCV 229E and MHV3. J Gen Virol 1980; 49: 83-9.

23 Brandt CD, Kim HW, Vargosko AJ, et al. Infections in 18,000 infants and children in a controlled study of respiratory tract disease. I. Adenovirus pathogenicity in relation to serologic type and illness syndrome. Am $J$ Epidemiol 1969; 90: 484-500.

24 MacNaughton MR. Occurrence and frequency of coronavirus infections in humans as determined by enyzme-linked immunosorbent assay. Infect Immun $1982 ; 38$ : 419-23.

Correspondence to Dr H B Valman, Northwick Park Hospital, Clinical Research Centre, Watford Road, Harrow, Middlesex HA1 3 UJ.

Received 25 March 1983 